\title{
Factors Influencing Communities to Conduct Duku Fruit Sale and Purchase Transactions with the Ijon System in Sugih Waras Village, South Sumatra in Indonesia
}

\author{
Nova Yanti Maleha ${ }^{1}$, Endah Dewi Purnamasari ${ }^{2}$ \\ \{nova@stebisigm.ac.id ${ }^{1}$, endahdps@uigm.ac.id ${ }^{2}$ \} \\ STEBIS IGM University Palembang, Indonesia ${ }^{1}$, UIGM University Palembang, Indonesia ${ }^{2}$
}

\begin{abstract}
The people of Sugih Waras Village, Teluk Gelam District, Ogan Komering Ilir Regency, South Sumatra Province carry out the sale and purchase transactions of duku fruit using the bonded system. Ijon in Arabic is called mukhabarah, which is trading fruit or seeds that are still green. Commonly known as al-muhaqalah, namely selling when he was a child and the goods were unclear. This study aims to determine the internal and external factors that influence the sale and purchase of duku fruit on the bonded bond system. This research used qualitative data type using field research. The results of this study indicate that there are internal factors, internal and external factors that influence the buying and selling of Ijon in Sugi Waras Village. Internal factors meet needs, seek large profits, while external factors greatly influence the sale and purchase of bonded bonds due to cultural factors, group references, and situational factors.
\end{abstract}

Keywords: Buying and selling, bonded bond system, internal and external factors

\section{Introduction}

Islam is a perfect religion, meaning that it regulates all human activities, be it politics, state administration, law, social culture, economics, or others. One form of interaction is the stipulation of a sale and purchase contract. Meanwhile, buying and selling according to civil law is an agreement whereby one party binds it to deliver an object and the other party to pay the price that has been promised. [1] Furthermore, buying and selling according to Syria 'is an exchange for assets exchanging permissible benefits for permanent benefits, not usury and not debt.[2]

Also, according to Islam, in carrying out buying and selling transactions, there must be clarity in the object to be traded. Thus, if an item is traded and the object of its condition cannot be determined, the sale and purchase are invalid or canceled. One of the problems in muamalah is buying and selling using the bonded bond system. The Ijon system or in Arabic is called Mukhadarah, which is trading fruit or seeds that are still green. From this understanding, it appears that there is a difference between selling fruit or seeds that are still on a branch but have a visible good form and selling fruit or seeds whose goodness cannot be ascertained because they are not visible in their ripe form. [3]

Duku fruit is a seasonal fruit that is only in season once a year. Duku fruit is a source of income for the community in Sugi Waras Village, Teluk Gelam District, Ogan Komering Ilir Regency by conducting buying and selling transactions when duku fruit is still small or what is commonly known as the bonded bond system.

Based on the observations and interviews of researchers, the researcher interviewed one of the farmers in Sugih Waras Village, he said that the practice of buying and selling duku fruit with the ijon system in Sugih Waras Village was carried out with the seller sometimes they offer prospective buyers to buy young fruit (not yet ready to harvest) sometimes the buyer also bids and asks the owner of the fruit to sell the fruit when it is not yet fit for harvest, even though the harvest is done on time. Usually, the buying and selling of duku fruit are carried out in the number of trees, for example, one tree, or several trees depending on the agreement to determine the number of fruits on the tree using an estimation system. In determining the price of fruit, the seller usually determines the number of trees and the number of duku fruits that appear on the farmer's tree. 
After seeing the plants, and having made an estimate, then the price is set, then proceed with negotiations between the seller and the buyer by mutual agreement.

This system has often been used by sellers or farmers of duku fruit, especially in Sugih Waras Village, Teluk Gelam District, Ogan Komering Ilir Regency. Meanwhile in Islam itself, buying and selling plants that are not ready for harvest is illegal and prohibited because the yield and shape are not clear.[4] The definition of buying and selling according to start 'is the exchange of property for property to own and give ownership. Some scholars give the understanding that what is meant by buying and selling is the exchange of assets even though there is still a liability or a changeable benefit for something such as both, to give permanently.

\section{Literature Review}

\subsection{Understanding Selling Bell}

Buying and selling in Indonesian from two words, namely buying and selling. The meaning of buying and selling is trading, trading, sell, and buy goods. [5]

\subsection{The Legal Basis of Buying and Selling}

Buying and selling is a contract that is allowed based on the Koran, Sunnah, and Ijma 'ulama'. Buying and selling as a means of helping human beings have a very strong foundation in Islam.[3]

\subsection{Pillars and Terms of Sale and Purchase}

According to Imam Nawawi, in syarah al-Muhadzab, harmonious buying and selling include three things, namely: 1 . There must be a quid (person who does the contract), 2. ma'qud alaihi (goods that are accredited), and 3. sighat, which consists of consent (offering) qabul (acceptance).

\subsection{Prohibited Forms of Buying and Selling}

Trading that is prohibited is divided into two: first, buying and selling that is prohibited and the law is invalid (canceled), namely buying and selling that do not meet the requirements and harmony. The second is buying and selling which is legal but prohibited, namely buying and selling that have met the requirements and are in harmony. Several factors hinder the ability of the buying and selling process.[6]

Benefits of Buying and Selling:

1. The benefits of buying and selling Buying and selling can organize the structure of the economic life of society that respects the property rights of others.

2. Sellers and buyers can meet their needs on a voluntary or consensual basis.

2. Understanding the buying and selling of Ijon in Islamic law

Ijon in Arabic is called mukhabarat, which is trading fruit or seeds that are still green. Or what is commonly known as al-muhaqalah, namely selling agricultural products before they appear or selling when they are young and the goods are not clear.

3. Factors Affecting the Buying and Selling of Ijon

Internal factors: 1. To meet basic needs, 2. Human greed and 3. Lack of religious knowledge.

External Factors: 1. External Factors, 2. Reference Groups and 3. Situational Factors.

\section{Methodology}

\subsection{Research sites}

The research location is the place where research is conducted. This research was conducted in Sugih Waras Village, Teluk Gelam District, Ogan Komering Ilir Regency, South Sumatra Indonesia.

\subsection{Types of research.}

This type of research uses qualitative data and in the form of data from the results of direct interviews with the people of Sugih Waras Village, Teluk Gelam District, Ogan Komering Ilir Regency, South Sumatra Indonesia.

\subsection{Data source.}

In this study, there are two sources of data used, namely primary data and secondary data. Primary data is data obtained by researchers from sources[7]. What is obtained by using field 
studies and direct interviews regarding the procedures for buying and selling duku by ijon to the fruit owner or seller? Meanwhile, secondary data was collected through the documentation at the Sugih Waras Village Hall and books that were relevant to the existing problems.

\subsection{Population and Sample.}

The population is the subject of research. If someone wants to research all the elements that exist in the research area, then the research is a population study. The sample is a portion of the number and characteristics of that population. According to Suharsimi Arikunto, if the subject is less than 100, it is better to take all of them so that the research is a population study. [8] In this study, because it was less than 100, according to the existing theory, this study became the entire population as a sample in the study.

\subsection{Data collection technique.}

Data collection technique uses the following steps:

2. The observation method of data collection begins with making observations or observations with some farmers or sellers of duku fruit in the village of Sugi Wars. This method is carried out to see the objective atmosphere of the buying and selling behavior of duku fruit in Sugi Waras Village, Teluk Gelam District, Ogan Komering Ilir Regency, buying the practice of duku fruit and the meaning seen by the behavior.

3. Interview method used to find out their opinion about the behavior of buying and selling duku by ijon in Sugi Wara village. Interviews have been prepared with a list of questions regularly.

4. The method of documentation, the author studies in detail about the behavior of buying and selling duku by ijon in the village of Sugi Waras District and is used to obtain data from documented sources. Especially regarding the population, religious understanding, and data related to the problem.

\subsection{Data analysis technique.}

The collected data were then analyzed qualitatively. Qualitative data analysis is an effort made by working with data, organizing data, selecting it into manageable units, synthesizing it, looking for and finding patterns, discovering what is important and what is learned, and deciding what others can tell.

\section{Result And Discussion}

This data collection was carried out by interviewing some of the Sugih Waras Village community. This interview was conducted in Sugih Waras Village, Teluk Gelam District, Ogan Komering Ilir Regency, to get the results of buying and selling transactions using the bonded bond system.

Analysis of Factors Affecting the Buying and Selling of Ijon in Sugih Waras Village, Teluk Gelam District. Based on the results of interviews with farmers in Sugih Waras Village, several factors influence the community to buy and sell duku fruit with the bonded system:

\subsection{Internal Factors.}

Several internal factors influence the community in Sugih Waras Village, Teluk Gelam District, Ogan Komering Ilir Regency to make buying and selling transactions using the bonded bond system

a. To meet basic needs

Data were collected by interviewing 30 farmers, the results of the interview showed that $70 \%$ of the people made the purchase and purchase of bonded bonds because it was to fulfill daily basic needs that had to be fulfilled every day so that people made buying and selling transactions of dukunya fruit faster using the bonded system. and 30\% to get money from the duku fruit faster without having to wait long and go through the process until the harvest arrives .

b. Looking for big profits.

The author conducted interviews with 30 farmers, from the results of the interviews, it was illustrated that $70 \%$ of the community-made bonded buying and selling because they wanted to get a bigger profit than the usual transaction, and $30 \%$ chose to wait to sell their dukunya fruit when it was ready to harvest. Apart from necessities, the desire to get a large profit also greatly affects the buying and selling of duku fruit using the bonded bond system, farmers feel that they benefit 
maximally from the bonded trading system and are considered practical. Where they do not think about the advantages or disadvantages of the buyer. Even though they often experience losses, they still want to make buying and selling transactions with this bonded bond system because they expect to get profits on future transactions .

c. Lack of Religious Knowledge.

From the results of the interview, it is illustrated that $70 \%$ of the people admit that they do not know about the prohibition of transactions that they do in Islam, and 30\% claim to know but still choose to carry out their sale and purchase transactions using the ijon system, most of the people do not know that the transactions they have made so far are not appropriate with Islamic law. They think if what they do is right, as long as they don't steal, don't commit fraud, they think there is no problem.

d. They are lazy and want to be practical.

Here it can be seen that $50 \%$ of people who buy and sell duku fruit with the ijon system in Sugi Waras Village are because they feel they want to be practical through the processes of waiting for duku fruit until the harvest time arrives, and do not want to bother selling and offering back duku that has been harvested considering the transportation costs, and not to mention other disturbances. When the harvest comes, the buyer usually comes and harvests the ripe duku fruit which is then packed in wooden crates and covered with newspaper. In transporting duku fruit that has been harvested, the buyer usually transports it directly. This bonded bond system transaction is considered easier and more practical because it saves time and effort. After all, there is no need to wait for the harvest to arrive and there is no need to spend energy to collect the harvest. However, based on a survey by researchers, $50 \%$ of the people prefer to go through all the processes until the harvest time arrives.

\subsection{External Factors.}

External factors are factors that come from outside a person or individual, this factor includes the people around, the environment and includes those closest to them. Several external factors influence the community in Sugi Waras Village, Teluk Gelam District, Ogan Komering Ilir Regency to make buying and selling transactions using the bonded bond system.

a. Cultural factors.

Based on the results of the interview, the reason why people buy and sell duku fruit with the ijon system is that this transaction has been happening for a long time and has become a culture in Sugih Waras Village, there are $75 \%$ that causes people to buy and sell duku fruit with this ijon system due to factors a culture that has become a tradition and hereditary so that farmers have been accustomed to buying and selling bonds for a long time and this habit has become a culture in the village].

b. Reference Groups.

Based on the results of the interview, it can be seen that $20 \%$ of the reasons why people make bonded transactions are because they are curious about this bonded buying and selling transaction system. $50 \%$ because of an invitation from farmers who buy and sell using the bonded system and get a lot of profit, thus influencing and inviting other farmers to also participate in buying and selling duku fruit with the bonded system Farmers feel very benefited from buying and selling Duku fruit with this bonded system, so they invite relatives, friends and neighbors to share in the benefits. This is what causes more and more people to participate in buying and selling with this system and influencing other people to try to make buying and selling transactions of duku fruit with the bonded system, and the persistence of farmers who have often made bonded buying and selling transactions affect other farmers who have never done it to try and make a profit.

c. Situational Factors

The author conducted interviews with 30 farmers. Based on the results of the interview, $60 \%$ of the people carry out the sale and purchase of duku fruit with the bonded system due to situational factors, the urgent need for costs that cause this transaction, and $30 \%$ because it requires fast costs for business capital. Farmers admit that they often offer duku fruit at belowmarket prices to quickly find buyers. From these results, it can be seen that situational factors also greatly affect the reasons for the community to buy and sell duku fruit with this bonded system. The lack of understanding and public awareness of the religion of the farmers in Sugi Waras Village towards buying and selling with the bonded bond system affects the way they behave in 
buying and selling that does not comply with Islamic law. To meet the necessities of life, farmers buy and sell in this way, even though in Islam the buying and selling of ijon are prohibited.

\section{Conclusion}

Based on the results of the discussion, it can be understood that the factors that influence the buying and selling of bonds in Sugi Waras Village are from internal factors, namely factors to meet needs. The daily necessities of life are increasing to make farmers sell their crops using bonded labor, even though it has been prohibited by Islamic law. The great profit-seeking factor. Humans also influence the decisions or reasons why buyers and sellers continue to buy and sell bonds, even though the possibility of loss can also occur, ambitious and great desire in life and a lack of gratitude, this also affects the community to seek large profits and then make buying and selling Duku fruit using the bonded system. Furthermore, some factors are lazy and want to be practical in the community, this also greatly influences the existence of bonded transactions in Sugih Waras village, Teluk Gelam District.

Meanwhile, external factors that greatly influence the buying and selling of bonded bonds in Sugih Waras village are cultural factors, group references, and situational factors. A group is a figure or a certain group of people in a community that is used or referred by a person or group in forming views about the value of attitudes or as a guide for behavior. With the existence of someone who trades with the bonded bond system and is proven to get a lot of profit, so many other farmers also participate in buying and selling using this system.

\section{References}

[1] R. A. sohari sahrani, Fikih Muamalah. Bogor: Ghalia Indonesia, 2011.

[2] A. wardi Muslich, Fiqih muamalah. Jakarta: Amzah, 2010.

[3] A. Hasan, Berbagai Macam Transaksi Dalam Islam (Fiqh Muamalat). Jakarta: Raja Grafindo Persada, 2010.

[4] Mardani, Fiqh Ekonomi Syariah :Fiqh Muamalah. Jakarta: Prenada Media Grup, 2012.

[5] A. dkk As-sa'id, Fiqih Jual Beli : Panduan Praktis Bisnis Syariah. Jakarta: Senayan Publising, 2008.

[6] abdul rahman G. sapiudin, ghufron ihsan, Fiqh Muamalah. Jakarta: Prenada Media Grup, 2012.

[7] Muhammad, Metodologi Penelitian Ekonomi Islam. Jakarta: Rajawali Pers, 2013.

[8] S. Arikunto, ProsedurPenelitian Suatu Pendekatan Pratik. Jakarta: Rineka Cipta, 2013. 